\title{
Hyperspectral One-Meter-Resolution Remote Sensing in Yellowstone National Park, Wyoming: II. Biomass
}

\author{
Mustafa Mirik, ${ }^{1}$ Jack E. Norland, ${ }^{2}$ Robert L. Crabtree, ${ }^{3}$ and Mario E. Biondini ${ }^{4}$ \\ Authors are ${ }^{1}$ Assistant Research Scientist, The Texas A®M University System, Texas Agricultural Experiment Station, \\ 2301 Experiment Station Road, Bushland, TX 79012; ${ }^{2}$ Research Specialist, Animal and Range Sciences, North Dakota State \\ University, Hultz Hall, Fargo, ND 58105; ${ }^{3}$ Chief Scientist, Yellowstone Ecological Research Center, 2048 Analysis Drive, Suite B, \\ Bozeman, MT 59718; and ${ }^{4}$ Professor, Animal and Range Sciences, North Dakota State University, Hultz Hall, Fargo, ND 58105.
}

\begin{abstract}
This study was designed to determine the utility of a 1-m-resolution hyperspectral sensor to estimate total and live biomass along with the individual biomass of litter, grasses, forbs, sedges, sagebrush, and willow from grassland and riparian communities in Yellowstone National Park, Wyoming. A large number of simple ratio-type vegetation indices (SRTVI) and normalized differencetype vegetation indices (NDTVI) were developed from the hyperspectral data and regressed against ground-collected biomass. Results showed the following: 1) Strong relationships were found between SRTVI or NDTVI and total $\left(\mathrm{R}^{2}=0.87\right)$, live $\left(\mathrm{R}^{2}=0.84\right)$, sedge $\left(\mathrm{R}^{2}=0.77\right)$, and willow $\left(\mathrm{R}^{2}=0.66\right)$ biomass. 2$)$ Weak relationships were found between SRTVI or NDTVI and grass $\left(\mathrm{R}^{2}=0.39\right)$, forb $\left(\mathrm{R}^{2}=0.16\right)$, and litter $\left(\mathrm{R}^{2}=0.51\right)$ biomass, possibly caused by the mixture of spectral signatures with grasses, sedges, and willows along with the variable effect of the litter spectral signature. 3) A weak relationship was found between sagebrush biomass and SRTVI or NDTSI $\left(\mathrm{R}^{2}=0.3\right)$ that was related to interference from sagebrush photosynthetic or nonphotosynthetic branch and twig material, and from the indeterminate spectral signature of sagebrush. This study has shown that hyperspectral imagery at $1-\mathrm{m}$ resolution can result in high correlations and low error estimates for a variety of biomass components in rangelands. This methodology can thus become a very useful tool to estimate rangeland biomass over large areas.
\end{abstract}

\section{Resumen}

Este estudio fue diseñado para determinar la utilidad de los sensores remotos de tipo hiperespectral de $1 \mathrm{~m}^{2}$ de resolución para estimar la biomasa total y viva, junto con la biomasa individual del mantillo, zacates, hierbas, juncos, "Sagebrush" y "Willow" de un pastizal y comunidades ribereñas del Parque Nacional de Yellowstone, WY. A partir de los datos de los sensores hiperespectrales se desarrolló un gran número de índices del tipo de relación simple (SRTVI) e índices del tipo de Diferencia Normalizada de Vegetación (NDTVI) y se calcularon regresiones de estos índices con los datos de biomasa colectados en el terreno. Los resultados mostraron que: 1) Se encontraron relaciones fuertes entre SRTVI o NDTVI y la biomasa total $\left(\mathrm{R}^{2}=0.87\right)$, biomasa viva $\left(\mathrm{R}^{2}=0.84\right)$, biomasa de juncos $\left(\mathrm{R}^{2}=0.77\right)$ y biomasa de "Willow" $\left.\left(\mathrm{R}^{2}=0.66\right) .2\right)$ Se detectaron relaciones débiles entre SRTVI o NDTVI y la biomasa de zacates $\left(\mathrm{R}^{2}=0.39\right)$, hierbas $\left(\mathrm{R}^{2}=0.16\right)$ y mantillo $\left(\mathrm{R}^{2}=0.51\right)$, posiblemente como consecuencia de la mezcla de señales espectrales provenientes de las gramíneas, juncos y "Willows", así como de los efectos variables de las señales generadas por el mantillo, 3) Encontramos también una relación débil $\left(\mathrm{R}^{2}=0.3\right)$ entre SRTVI o NDTVI y la biomasa del "Sagebrush", que fue relacionada con la interferencia del material de las ramas y ramillas fotosintéticas y no fotosintéticas, así como con la señal indeterminada generada por el "Sagebrush". Los resultados de este estudio han mostrado que las imágenes hiperespectrales con una resolución de $1 \mathrm{~m}^{2}$ pueden proveer correlaciones altas y estimaciones de bajo error para una variedad de componentes de biomasa de los pastizales. Por lo tanto, esta metodología, puede llegar a ser una herramienta muy útil para estimar la biomasa de grandes áreas de pastizal.

Key Words: vegetation indices, grassland, riparian, standing crop

\section{INTRODUCTION}

Biomass or standing crop estimations on rangelands are some of the main parameters used in range management. One technique that has been shown to be useful for estimating biomass over large areas is remote sensing (Tueller 2001; Wylie

Research supported by the NASA Earth Observations Commercial Applications Program-Hyperspectral, the Ministry of National Education of the Republic of Turkey, the National Science Foundation (DEB-9627928), and the USDA-NRICGP (93-00501 and 9900979). We would like to thank the people in these organizations.

Correspondence: Dr. Jack Norland, Animal and Range Sciences, North Dakota State University, Hultz Hall, Fargo, ND 58105. Email: jack.norland@ndsu.nodak.edu

Manuscript received 1 February 2004; manuscript accepted 14 June 2005. et al. 2002). Previous remote sensing studies using broadband multispectral systems with ground resolutions of $30 \mathrm{~m}$ to $1 \mathrm{~km}$ resulted in a broad range of reliability, accuracy, and precision. Hyperspectral systems measure the electromagnetic spectrum in continuous narrow spectral channels in the 400-2 $500 \mathrm{~nm}$ portion of the electromagnetic spectrum. The hyperspectral approach has been found to have advantages over multispectral systems for estimating vegetation in a variety of settings (Gamon et al. 1993; Roberts et al. 1993, 1997; Gamon and Qui 1999; Thenkabail et al. 2000; Kumar et al. 2001). It is anticipated that the development of hyperspectral devices with resolutions of 1 to $5 \mathrm{~m}$ should substantially advance our ability to measure vegetation (Kumar et al. 2001). Tueller (2001), in a review of hyperspectral systems, concluded that they represent 
a very promising technology for estimating rangeland biomass, but that empirical studies are still needed to demonstrate their utility for range management.

Rangeland components such as forbs, grasses, shrubs, litter, and bare ground are critical in the estimation of rangeland biomass. These components tend to occur as heterogeneous mixtures at the resolution level of most sensors, but even at 1-m resolution several different components can be found within a single pixel (Gamon and Qui 1999; Asner et al. 2000), thus the best pixel size for biomass estimations has always been an issue of significant discussion (Rahman et al. 2003). It is nevertheless assumed that investigations of vegetation biomass at the meter scale will improve estimation and provide necessary information on the spatial variability of vegetative biomass.

Pixel size is also a problem when it comes to matching ground information to sensor measurements. With large pixel sizes ( $>5 \mathrm{~m}$ ), matching ground information to sensor measurements requires subsampling since there are few ground methods capable of measuring vegetation at resolutions of $5 \mathrm{~m}$ or more. Unfortunately, subsampling introduces measurement errors (Curran and Williamson 1986; Dungan 1998). Remote sensing methods that match ground to sensor information on a pixelby-pixel basis are thus preferred.

The objective of this study was to determine the utility of a 1-m-resolution hyperspectral sensor to estimate total and live biomass along with the individual biomass of litter, grasses, forbs, sedges, sagebrush, and willow from the grassland and riparian communities in Yellowstone National Park, Wyoming.

\section{METHODS AND MATERIALS}

\section{Study Site}

The location and description of the study site can be found in a companion article on forage nutritional values by Mirik et al. (2005).

\section{Ground Data Collection}

A total of 56 ground data plots, each measuring $1 \times 1 \mathrm{~m}$, were used to collect biomass. The plot size matched the spatial resolution of the hyperspectral remote sensing system used in this study. The plot locations were selected to represent the range of biomass values for the different biomass components. Plots were not randomly selected because the objective of the study was to develop equations to relate ground to hyperspectral data over the whole range of biomass values expected at the site. To randomly sample the study area and still have the same range of biomass values would have required many more plots than the logistics of the study could accommodate (plots have to be clipped in a narrow window of days after the flight of the hyperspectral instrument). Because of the match between the ground plot size $\left(1 \mathrm{~m}^{2}\right)$ and the remote sensing pixel resolution $\left(1 \mathrm{~m}^{2}\right)$ there was no need to subsample within the ground plots.

The method for coregistering the ground data plots with the image pixels was described in a companion article on forage nutritional values by Mirik et al. (2005).

The ground data were collected in the period from 7 August 1999 to 12 August 1999, which was 5 to 10 days after the hyperspectral image was taken. Ground data plots were scattered over the various plant communities with samples in xeric grassland, mesic grassland, willow, sagebrush, and sedge communities. Grasses, sedges, and forbs were identified and clipped to the ground level. Litter was collected by clipping all standing dead material and pulling from within the ground data plot any dead plant material that was laying on top of the ground surface. Sagebrush and willow leaves (nonwoody portions) were stripped by hand. Vegetation samples were weighed after oven drying at $60^{\circ} \mathrm{C}$ for at least 48 hours. Total biomass is the sum of all the different component biomass in the plots. Live biomass included all components within a plot except standing dead material and litter.

\section{Spectral Data Collection}

The hyperspectral data were collected on 2 August 1999 using the PROBE-1 hyperspectral imagery system, which was described in a companion article on nutritional forage values by Mirik et al. (2005).

\section{Statistical Analyses}

A large number of simple ratio-type vegetation indices (SRTVI) and normalized difference-type vegetation indices (NDTVI) were calculated using the hyperspectral measurement digital number from the majority of the bands as follows: SRTVI $=$ Band $1 /$ Band 2; NDTVI $=($ Band $1-$ Band 2$) /($ Band $1+$ Band 2) where Band 1 and Band 2 are the digital numbers from the selected bands in the imagery. For Band 1 all the available bands between 707.5 and $2506.7 \mathrm{~nm}$ of the electromagnetic spectrum were used, for a total of 107 separate bands. For Band 2 all available bands between 437.9 and $2506.7 \mathrm{~nm}$ were used, for a total of 127 separate bands. The wavelength values reported represent the midpoint of each band. Indices have previously been used in hyperspectral approaches (Thenkabail et al. 2000). By using a large number of indices, the various regions along the electromagnetic spectrum that correlate well with biomass measurements can be adequately identified because of the narrow width of the hyperspectral bands.

All the imagery analyses were conducted using the Environment for Visualizing Images (ENVI 2000) software package (Research System, Inc., Boulder, CO). Indices and ground data plots were matched and analyzed in SAS (1999) (SAS Institute, Inc., Cary, NC) using PROC REG regression procedure set to the MAXR model-selection method. The MAXR model-selection method identifies the best 1-variable model, with the highest $R^{2}$ (SAS, 1999), relating the various ground biomass measurements to SRTVI or NDTVI. The SRTVI or NDTVI were set as the independent variable and the ground biomass measurements set as the dependent variable.

\section{RESULTS}

Strong to weak linear relationships (high or low $\mathrm{R}^{2}$ ) were found between a selected subset of SRTVI and NDTVI derived from the 1-m-resolution hyperspectral measurements and the various biomass components (Figs. 1 and 2). The number of samples used for each analysis varied, with grass, forbs, and litter being present in most plots but sedge, willow, and sagebrush being present in only those plots from their respective communities (Table 1). Samples displayed a large range in values for each component and were representative 

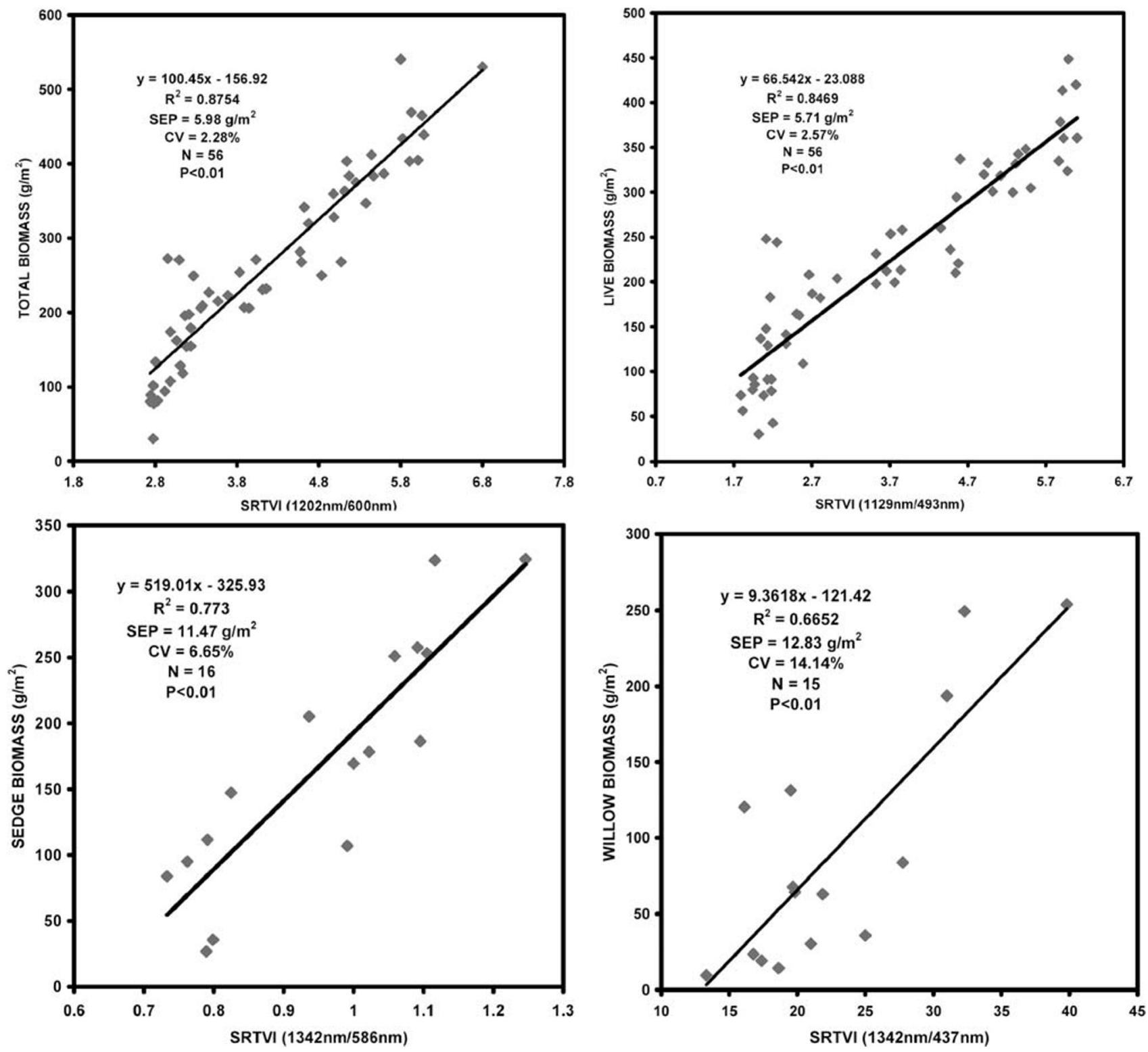

Figure 1. Regressions between various biomass components and selected simple ratio-type vegetation index (SRTVI). SEP indicates standard error of prediction; CV, coefficient of variation; and N, number of observations.

of the range of values found within the study site and surrounding area.

The linear relationship between both total and live biomass and their selected SRTVIs displayed very strong relationships and low errors (Fig. 1). All 56 plots were used to develop the relationships so they include information from the various other components as well as all the plant communities: xeric, mesic, sagebrush, sedge, and willow. The sedge and willow component biomass had high $\mathrm{R}^{2}$ values, but not as high as those for total and live biomass (Fig. 1). The $\mathrm{R}^{2}$ for the litter biomass relationship (Fig. 2) was lower than those for sedge and willow but higher than the weak relationships for sagebrush, grass, and forb component biomass (Fig. 2).

Because of the inherent differences in moisture between the samples, the biomass samples of the litter, grass, and forb components were further stratified into drier types (plots from the xeric, mesic, and sagebrush communities) and moist types (plots from the sedge and willow communities) to see if stronger relationships would emerge. No statistically significant differences were found between the xeric and mesic regression of either forbs or litter and their nonstratified counterparts. Likewise the mesic regression of grasses was not different than the nonstratified ones. The regression from the xeric grass component did result in a higher $\mathrm{R}^{2}$ (Fig. 3) when compared to the nonstratified dataset (Fig. 2).

To better understand the influence that sagebrush biomass has on plot level reflectance, we conducted regressions in the sagebrush plots with and without the sagebrush biomass component. The relationship between total plot biomass and hyperspectral measurements was much stronger without the sagebrush component (grass, forbs, and litter biomass) (Fig. 4, $\left.\mathrm{R}^{2}=0.9\right)$ than with it $\left(\mathrm{R}^{2}=0.73\right)$.

The SRTVI or NDTVI with the best relationships for the various biomass components used the near-infrared part of 

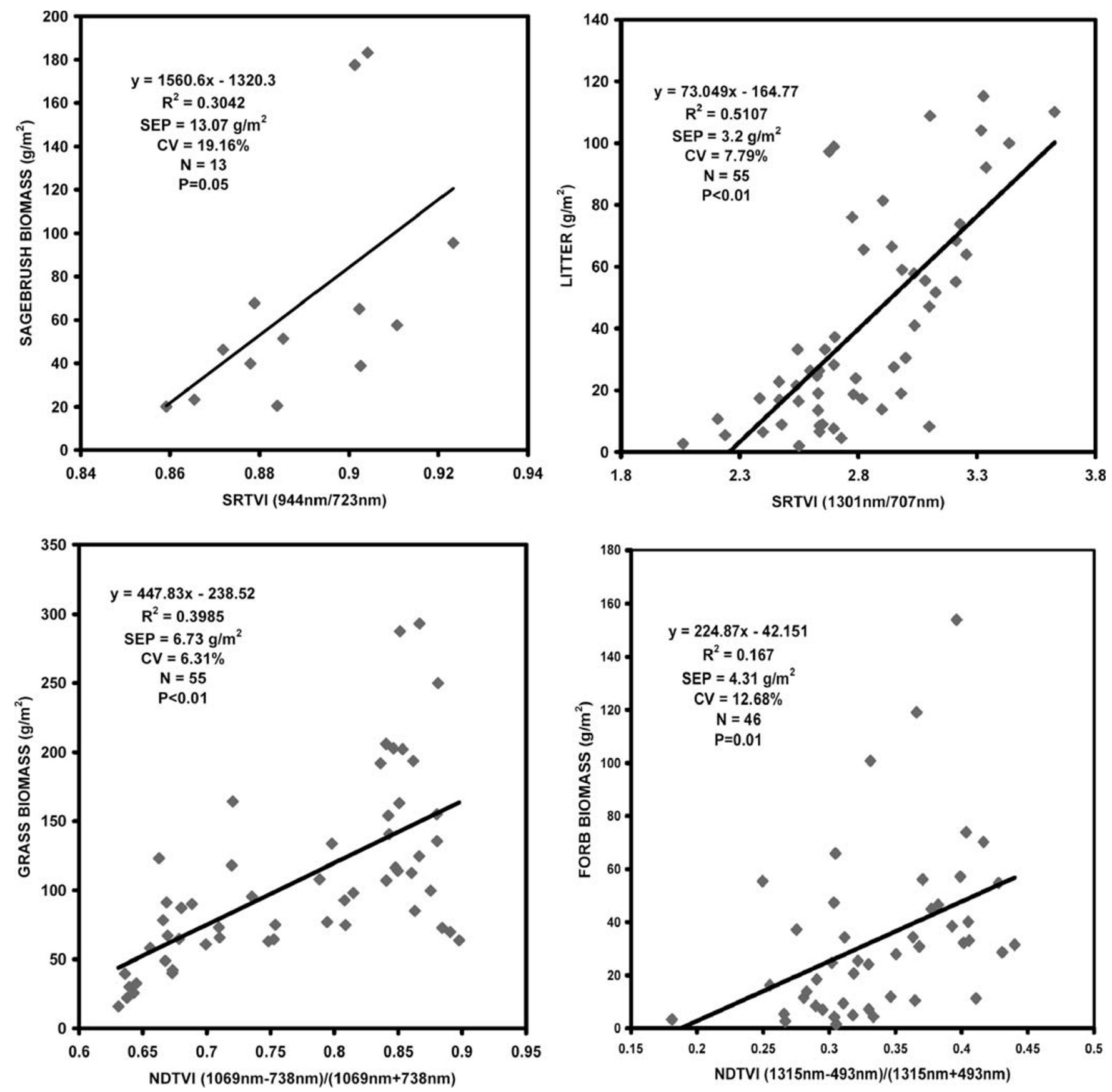

Figure 2. Regressions between various biomass compenents and selected simple ratio-type vegetation index (SRTVI) or normalized difference-type vegetation index (NDTVI). SEP indicates standard error of prediction; CV, coefficient of variation; and N, number of observations.

the spectrum for Band 1 (900-1 $360 \mathrm{~nm}$ ) and the visible as well as near-infrared part of the spectrum for Band 2. SRTVI and NDTVI that used the short-wavelength infrared part of the spectrum for Band 1 had significant $(P<0.05)$ relationships with the various biomass components but had lower $\mathrm{R}^{2}$ than did the ones shown in the various figures.

\section{DISCUSSION}

The strong relationships we found between total and live biomass and the 1-m-resolution hyperspectral measurements agree with the results from other remote sensing studies in rangeland settings (Gamon et al. 1993; Wylie et al. 1996; Todd et al. 1998; Tueller 2001; Kumar et al. 2001). Because all 56 plots were used in the relationships representing a gradient from mesic/riparian/wetland vegetation types through xeric/ upland vegetation types, estimates can be applied to the full range of plant communities and biomass amounts found on the site. The influence of different component amounts, such as litter, and the broad range of biomass amounts did not affect the relationships. Other studies that used $>1-\mathrm{m}$ resolution imagery found that litter, bare ground, land use, and species differences all had varying influence on biomass relationships 
Table 1. Sample size, mean, standard deviation (SD) and range for the different vegetative biomass components collected in the $1-\mathrm{m}^{2}$ ground data plots.

\begin{tabular}{lcccr}
\hline Component & $\begin{array}{c}\text { Sample } \\
\text { size }\end{array}$ & $\begin{array}{c}\text { Mean } \\
\left(\mathrm{g} \cdot \mathrm{m}^{-2}\right)\end{array}$ & SD & $\begin{array}{c}\text { Biomass } \\
\text { range }\left(\mathrm{g} \cdot \mathrm{m}^{-2}\right)\end{array}$ \\
\hline Litter & 55 & 41 & 33.6 & $2-115$ \\
Grass & 55 & 106.6 & 63.8 & $16-293$ \\
Forb & 46 & 34 & 31.7 & $2-154$ \\
Sedge & 16 & 172.3 & 93 & $27-324$ \\
Willow & 15 & 90.7 & 82.7 & $9-254$ \\
Sagebrush & 13 & 68.2 & 54.1 & $20-183$ \\
Total biomass & 56 & 262.3 & 125.6 & $30-540$ \\
Green biomass & 56 & 222 & 108.1 & $30-448$ \\
\hline
\end{tabular}

(Wessman et al. 1997; Todd et al. 1998; Asner and Lobell 2000; Asner et al. 2000). In addition, the higher biomass values did not result in lower correlations or higher errors as has been found in other rangeland settings (Wylie et al. 2002). These relationships represent a one-time estimate of peak vegetative biomass because the samples and image were taken in early August, which corresponds to peak biomass for much of the Yellowstone area.

Strong relationships were found between the sedge and willow component biomass and the hyperspectral measurements. These relationships can provide estimates that would be useful in range management. In contrast, weak relationships were found for the forb, grass, and litter component biomass. A reason for the weak relationships may be that other components are present at high enough levels to cause the remote sensing signal for the target components not to be spectrally distinct (Asner et al. 2000). Forbs tend to be a minor component in many of the plots and their reflectance may not be distinct from other more abundant biomass such as grass, sedge, or willow. Another reason for the poor relationships is that litter biomass not only affects the relationships of other components, but is itself affected by those components (Asner and Lobell 2000; Asner et al. 2000). The potential differences in reflectance characteristics of litter found in wet conditions compared to those in drier conditions may have also contributed to the weak relationships. This reasoning may point to why dividing the grass component into dry and wet subsets based on plant community resulted in a stronger relationship for the dry subset compared to the wet one.

The weak relationship between sagebrush biomass and hyperspectral measurements may have been caused by the presence of a large amount of photosynthetic or nonphotosynthetic branch and twig material interacting directly with incoming radiation in comparison to the amount of green leaves (Wylie et al. 1996; Todd et al. 1998; Asner and Lobell 2000). Wylie et al. (1996) found that live biomass in shrub-covered areas yielded significantly different relationships with vegetation indices when compared with grass-covered areas. Another reason for the weak relationship for the sagebrush component is that some arid-adapted shrubs may be spectrally indeterminate (Okin et al. 2001). If this is true, then the signal from the sagebrush leaves may not have any correlation with biomass amounts. Results from the exclusion of the sagebrush compo-

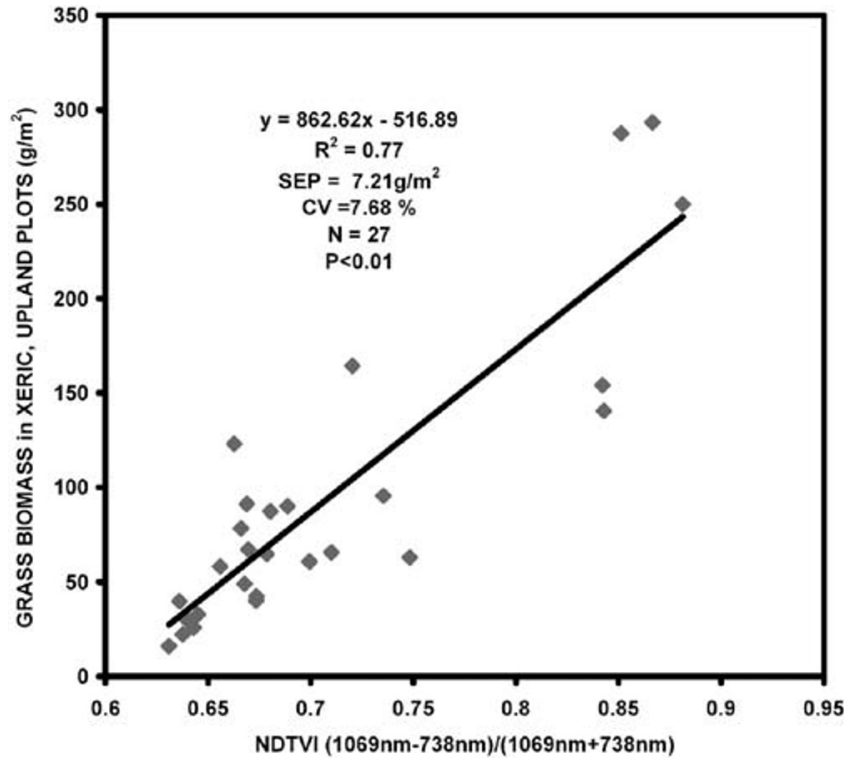

Figure 3. Regression between grass biomass from xeric, mesic, and sagebrush community plots (drier types) and a selected normalized difference-type vegetation index (NDTVI). SEP indicates standard error of prediction; CV, coefficient of variation; and N, number of observations.

nent biomass from total biomass estimations tend to support this lack of correlation (Fig. 4). The linear models were found to be stronger when the sagebrush component biomass was excluded than when it was kept (Fig. 4), leading us to conclude that the sagebrush component biomass signal was very weak in comparison to the signals from the other components. Excluding certain species from relationships with hyperspectral measurements has been shown in other studies to improve relationships between plant characteristics and remote sensing measurements (Todd et al. 1998; McGwire et al. 2000).

Because of the weak relationships between hyperspectral measurements and sagebrush biomass, the prediction of total biomass in sagebrush areas may thus require a combination of remote sensing methods for herbaceous and litter biomass and other data collection methods for sagebrush biomass that will have to be analyzed separately. Further investigation of the spectral properties of sagebrush and how to overcome its possible spectral indeterminate properties will require further work and innovative techniques, but, as cautioned by Okin et al. (2001), there are limits in the use of the hyperspectral approach to measure certain plants and their properties.

The stronger relationship for the drier subset of the grass component biomass compared to the wetter subset and the nonstratified component (Figs. 2 and 3 ) is probably due to the difference in the amount of water in the vegetation, soil surface background, and the components such as litter that contributed to spectral distortions (Gamon and Qui 1999). Because of these varying conditions, even hyperspectral approaches should incorporate flexibility into sampling designs so that contrasting environmental conditions can be separated to develop relationships with higher utility.

The fact that many of the relationships developed in this study used measurements from the electromagnetic spectrum not normally collected in multispectral systems strongly 

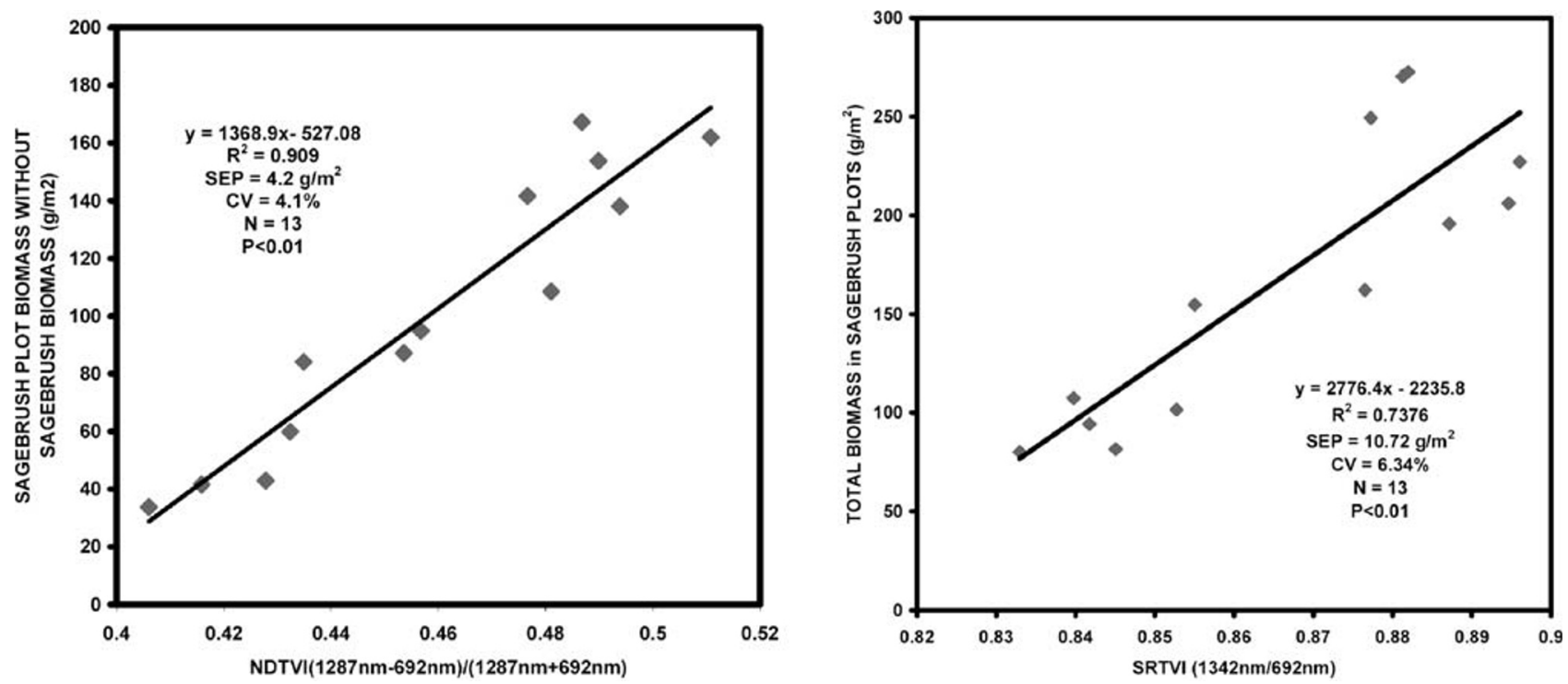

Figure 4. Regressions between sagebrush plot total biomass without the sagebrush component biomass (grass + forb + litter biomass) and a selected normalized difference-type vegetation index (NDTVI), and between sagebrush plot total biomass (sagebrush + grass + forb + litter biomass) and a selected simple ratio-type vegetation index (SRTVI). SEP indicates standard error of prediction; CV, coefficient of variation; and $\mathrm{N}$, number of observations.

supports the proposition that hyperspectral systems will increase the ability to measure biomass components important to rangeland management. These results have strong agreement with studies by Thenkabail et al. (2000) and Asner and Lobell (2000). The former study concluded that the widely used and well-known red and near-infrared band combinations, such as Landsat-5 TM-derived NDVI, are not necessarily the best for 2-band spectral vegetation indices designed to predict biophysical parameters in agricultural crop variables. Asner and Lobell (2000) pointed out that fractional abundances of green vegetation, bare soils, and standing and surface litter were better estimated using information from hyperspectral measurements. Our results support that proposition.

In this study, where both the ground sample size and the pixel size were identical, problems associated with subsampling the ground data and the error associated with that methodology were avoided. Due to our ability to match locations of the ground and image pixel exactly, errors due to mismatched ground locations were reduced. These errors still may occur if, instead of using an air photo approach, the matching is conducted using GPS-located ground samples and georectified image pixels because there are often substantial errors in both the GPS locations and the georectifcation process. The experimental errors present in our research were only those that resulted from the signal:noise ratio of the sensor and sensor viewing problems. The exact formulation of errors from predictions made with the regression methods that we applied in our research has been a recent area of discussion (Cohen et al. 2003). Formulations that take into account errors due to measurement from the sensor and ground information along with their spatial arrangement of the samples have been shown to produce more realistic estimates of the error term. Future work with the 1-m- to 5-m-resolution hyperspectral approach should consider these aspects when estimating biomass component errors.
In this study we used vegetation indices and simple regressions to develop the relationships between biomass and hyperspectral data. This type of analysis does not utilize all the possible information in the hyperspectral data set. Inclusion of more indices and combinations of indices in a multiple regression relationship along with nonlinear fitting should be considered since they may result in higher correlations and lower errors for certain components. Such an analysis would require larger datasets and attention to the details of the analysis to prevent violating assumptions and overfitting. Besides linear regression, other methods should be investigated, such as derivative transformations, modified partial least squares, linear mixture modeling, discriminant analysis, and principle component analysis among others.

\section{MANAGEMENT IMPLICATIONS}

This study has shown that hyperspectral imagery at 1-m resolution can result in high correlations and low error estimates for a variety of biomass components that have implications for rangeland management as follows:

1) Strong linear relationships were found between total, live, sedge, and willow biomass and SRTVI or NDTVI. From these strong relationships maps at a $1-\mathrm{m}$ scale can be produced over a large area. These maps can provide detailed spatial information on biomass components lacking from other sampling techniques and remote sensing sensors. Such maps could prove useful in rangeland management and research of animal distribution, grazing effects, ungulate modeling, ecological processes, and the effects of natural and man-made disturbances.

2) Weak linear relationships were found between litter, grass, and forb biomass components and SRTVI or NDTVI. These weak relationships were due to the mixture of the spectral signatures of grasses, sedges, and 
willows in mixed vegetation plots, and the variable effect of the litter's spectral signature.

3) The weak relationship found between sagebrush biomass and SRTVI or NDTVI was related to interference from sagebrush photosynthetic or nonphotosynthetic branch and twig material, and the indeterminate spectral signature of sagebrush. To predict total biomass in sagebrush areas would thus require a combination of remote sensing methods for herbaceous and litter biomass and other data collection methods for sagebrush biomass.

4) The promise of high spatial resolution hyperspectral imagery to provide useful estimates of certain biomass components was shown in this study, and we suggest that this technology and methodology should be considered when fine-scale maps are needed for rangeland management and research.

\section{LITERATURE CITED}

Asner, G. P., And D. B. Lobell. 2000. A biogeophysical approach for automated SWIR unmixing of soils and vegetation. Remote Sensing of Environment 74:99-112.

Asner, G. P., C. A. Wessman, C. A. Bateson, and J. L. Privette. 2000. Impact of tissue, canopy, and landscape factors on the hyperspectral reflectance variability of arid ecosystems. Remote Sensing of Environment 74:69-84.

Cohen, W. B., T. K. Maiersperger, S. T. Gower, and D. P. Turner. 2003. An improved strategy for regression of biophysical variables and Landsat ETM+ data. Remote Sensing of Environment 84:561-571.

Curran, P. J., and H. D. Williamson. 1986. Sample size for ground and remotely sensed data. Remote Sensing of Environment 20:31-41.

Dungan, J. 1998. Spatial prediction of vegetation quantities using ground and image data. International Journal of Remote Sensing 19:267-285.

ENVI. 2000. Environment for Visualizing Images User Guide. version 3.4, September 2000 Edition. Boulder, C0: Research System, Inc. 930 p.

Gamon, J. A., C. B. Field, D. A. Roberts, S. L. Ustin, and R. Valentini. 1993. Functional patterns in an annual grassland during an AVIRIS overflight. Remote Sensing of Environment 44:239-253.

Gamon, J. A., AND H.-L. QIU. 1999. Ecological applications of remote sensing at multiple scales. In: F. I. Pugnaire, \& F. Valladares [EDS.]. Handbook of functional plant ecology. New York, NY: Marcel Dekker. p. 805-845.
Kumar, L., K. Schmidt, S. Dury, and A. Skidmore. 2001. Imaging spectrometry and vegetation science. In: F.D. van der Meer and S. De Jong [EDS.]. Imaging spectrometry, basic principles and prospective applications. Dordrecht, The Netherlands: Kluwer Academic Publishers. p. 111-154.

McGwire, K., T. Minor, and L. Fenstermaker. 2000. Hyperspectral mixture modeling for quantifying sparse vegetation cover in arid environments. Remote Sensing of Environment 72:360-374.

Mirik M., J. E. Norland, R. L. Crabtree, and M. E. Biondini. 2005. Hyperspectral one-meter-resolution remote sensing in Yellowstone National Park, Wyoming: I. forage nutritional values. Rangeland Ecology and Management 58:452-458.

Okin, G. S., D. A. Roberts, B. Murray, and W. J. OKin. 2001. Practical limits on hyperspectral vegetation discrimination in arid and semiarid environments. Remote Sensing of Environment 77:212-225.

Rahman, A. F., J. A. Gamon, D. A. Sims, and M. Schmidts. 2003. Optimum pixel size for hyperspectral studies of ecosystem function in southern California chaparral and grassland. Remote Sensing of Environment 84:192-207.

Roberts, D. A., M. O. Smith, and J. B. Adams. 1993. Green vegetation, nonphotosynthetic vegetation, and soils in AVIRIS data. Remote Sensing of Environment 44:255-269.

RoberTs, D. A., R. O. Green, And J. B. AdAms. 1997. Temporal and spatial patterns in vegetation and atmospheric properties from AVIRIS. Remote Sensing of Environment 62:223-240.

SAS [Computer Program]. 1999. The SAS system for Windows. Version 8. Cary, NC: SAS Institute, Inc.

Thenkaball, P. S., R. B. Smith, and E. D. Pauw. 2000. Hyperspectral vegetation indices and their relationships with agricultural crop characteristics. Remote Sensing of Environment 71:158-182.

Todd, S. W., R. M. Hoffer, and D. G. Milchunas. 1998. Biomass estimation on grazed and ungrazed rangelands using spectral indices. International Journal of Remote Sensing 19:427-438.

TueleER, P. T. 2001. Remote sensing of range production and utilization. Journal of Range Management 54:A77-A89.

Wessman, C. A., C. A. Bateson, and T. L. Benning. 1997. Detecting fire and grazing patterns in tallgrass prairie using spectral mixture analysis. Ecological Applications 7:493-511.

Wylie, B. K., D. D. DeJong, L. L. Tieszen, And M. E. Biondinı. 1996. Grassland canopy parameters and their relationships to remotely sensed vegetation indices in the Nebraska Sand Hills. Geocarto International 11:39-52.

Wylie, B. K., D. J. Meyer, L. L. Tieszen, and S. Mannel. 2002. Satellite mapping of surface biophysical parameters at the biome scale over the North American grasslands: a case study. Remote Sensing of Environment 79:266-278. 